Prepared in cooperation with the Johnson County Stormwater Management Program

\title{
Water Quality of Streams in Johnson County, Kansas, 2002-07
}

\section{Teresa J. Rasmussen}

Water quality of streams in Johnson County, Kansas was evaluated from October 2002 through December 2007 in a cooperative study between the U.S. Geological Survey and the Johnson County Stormwater Management Program. Water quality at 42 stream sites, representing urban and rural basins, was characterized by evaluating benthic macroinvertebrates, water (discrete and continuous data), and/or streambed sediment. Point and nonpoint sources and transport were described for water-quality constituents including suspended sediment, dissolved solids and major ions, nutrients (nitrogen and phosphorus), indicator bacteria, pesticides, and organic wastewater and pharmaceutical compounds. The information obtained from this study is being used by city and county officials to develop effective management plans for protecting and improving stream quality. This fact sheet summarizes important results from three comprehensive reports published as part of the study and available on the World Wide Web at http:// ks.water.usgs.gov/Kansas/studies/qw/joco/

\section{Introduction}

Rapid population growth and urbanization in Johnson County in northeast Kansas has affected stream quality. Urbanization results in more residential, commercial, and industrial developments, and generally affects streams by altering hydrology, geomorphology, chemistry, and biology (Paul and Meyer, 2001); consequently, these changes affect aquatic communities. Contamination entering streams in rural and urban areas can originate from point sources (such as wastewater treatment discharges) and nonpoint sources (such as stormwater runoff, leaky sewer lines, septic tanks, and atmospheric deposition). Water quality in Johnson County streams affects downstream communities in the Kansas City metropolitan area because streams in basins covering about one-third of the county flow northeast into Missouri. Water quality and the effects of combined sewer overflows in Kansas City, Missouri, have been the subject of previous studies (Wilkison and others, 2006).
Streams in Johnson County are important for human and environmental health, water supply, recreation, and aesthetic value. The information obtained during this study is useful for defining current water-quality conditions, understanding variability in conditions, evaluating effects of urbanization, developing effective water-quality management plans, documenting changes in water quality, and evaluating conditions relative to total maximum daily loads (TMDLs), National Pollutant Discharge Elimination System (NPDES) requirements, and water-quality standards.

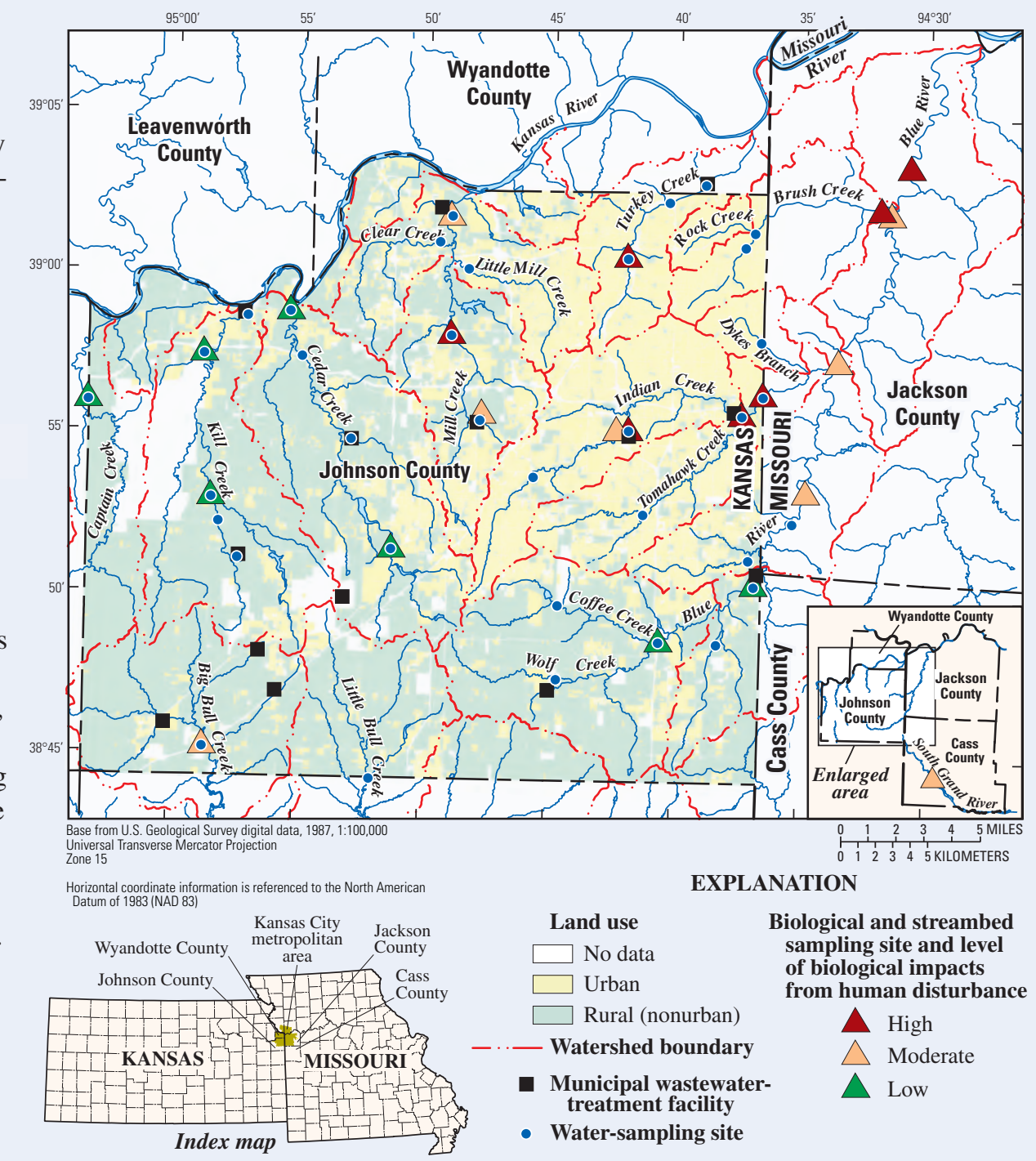

Figure 1. Location of stream sampling sites, urban and rural land use, and relative biological impacts (negative responses associated with human-induced disturbance or stress) in Johnson County, Kansas. 


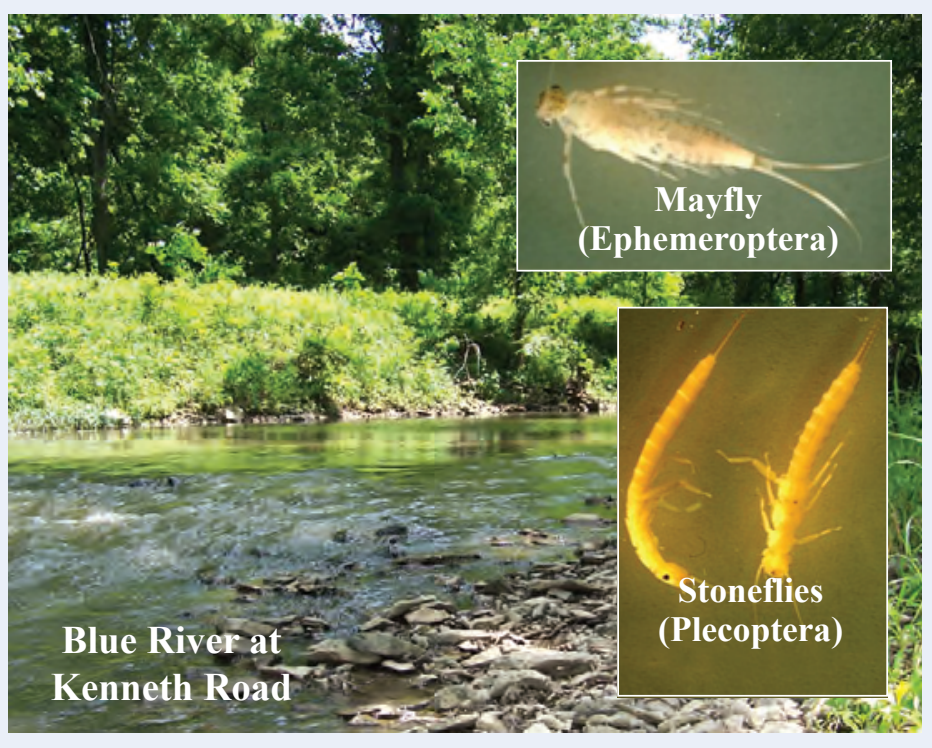

Figure 2. Example of a stream site in Johnson County, Kansas, showing minimal impacts from human disturbance and some macroinvertebrates generally associated with healthy streams (macroinvertebrate photographs from http://www.epa.gov/ bioindicators/html/photos_invertebrates.html).

Stream quality was evaluated from October 2002 through December 2007 using benthic macroinvertebrate, discrete water, and streambed sediment samples, and continuous water-quality monitoring. Macroinvertebrate samples were collected to assess biological conditions, an indication of how well water bodies support aquatic life and, therefore, a measure of overall stream quality. Macroinvertebrates were collected from 15 stream sites in Johnson County and evaluated along with data from seven additional sites collected as part of a separate study with similar objectives in Missouri (Wilkison and others, 2006). Various aspects of macroinvertebrate communities, including organism diversity (number and variety of species), composition, tolerance, and feeding characteristics also were used to evaluate and compare stream quality. Water samples were collected from 42 stream sites representing all of the major basins in the county (fig. 1, some sites represent multiple sampling locations). Water samples were analyzed for suspended sediment, dissolved solids and major ions, nutrients (nitrogen and phosphorus species), indicator bacteria, pesticides, and organic wastewater and pharmaceutical compounds. Samples were collected during baseflow (unaffected by storm runoff, when streamflow is sustained by ground-water inflow, springs, and, in some locations, wastewater discharge) and storm-flow conditions. Constituent concentrations, loads (amount of constituent transported in a stream during a specified period of time), and yields (load divided by drainage area for comparing basins) were determined for five major basins of Johnson County using continuous monitoring (hourly in-stream measurements) and statistical regression models. Streambed-sediment samples were collected from 15 sites and analyzed for major ions, nutrients, trace elements, bacteria, pesticides, and organic wastewater compounds. Unless otherwise referenced, the information summarized in this fact sheet is included in publications by Lee and others (2005), Poulton and others (2007), and Rasmussen and others (2008); additional explanation and results can be found in those reports.
Biological Conditions-An Overview of Stream Quality

- During 2003 and 2004 when biological samples were collected, no sites, including the reference site on Captain Creek, met State criteria (Kansas Department of Health and Environment, 2006) for full support of aquatic life. Reference streams are streams designated by the State as being minimally disturbed by human activity, and generally serve as a basis for comparison in stream evaluations.

- The least impacted stream sites predominantly were in rural areas (fig. 1). As impervious surface area (a general indication of urbanization) increased, biological quality generally decreased.

- Sites in Johnson County that were least impacted by human disturbance included upstream Blue River (fig. 2), Cedar, Kill, and Captain Creek sites (fig. 1). Indian, Tomahawk, and Turkey Creek sites in Johnson County, and downstream Blue River and Brush Creek sites in Missouri were most impacted by human disturbance.

- In the Blue River Basin where biological conditions were least impacted, biological quality was strongly correlated with upstream land cover consisting of forests and grasslands. Biological quality declined with increases in impervious land cover, nutrient enrichment, and prevalence of organic wastewater compounds and pharmaceuticals (Wilkison and others, 2006).

\section{Suspended Sediment}

- Of the total suspended-sediment load transported in 2005-06, 90 percent or more occurred during less than 2 percent of the time (the equivalent of about 7 days per year), generally during large streamflows, at all five monitoring sites. Therefore, management practices designed to control sediment during large streamflows can substantially reduce annual loads.

- About 35 percent larger average annual precipitation in 2005 compared to 2006 resulted in an average of four times the suspended sediment load.

- Annual sediment yields in the urban basins (Indian and Mill Creeks) were 50 percent larger than in rural basins (Cedar and Kill Creeks, Blue River) in 2005.

- About 70 percent of the time (generally when there was little or no storm runoff), suspended-sediment concentrations in Indian Creek were smaller than in other basins partly because of the large contribution of treated water discharged from upstream wastewater-treatment facilities. However, total annual sediment load and yield in Indian Creek were larger than other basins because of disproportional loading that occurred during large streamflow at that site.

- Sediment transport in Johnson County streams and, therefore, management practices implemented to control sediment are especially important because other contaminants such as nutrients and bacteria frequently are associated with sediment particles. 


\section{Nutrients and Dissolved Oxygen}

- In Johnson County stream reaches during 2005 and 2007, about two-thirds of the Indian Creek total nitrogen load and one-third of the Blue River total nitrogen load originated from wastewater treatment facilities (WWTFs) (fig. 3). Nitrogen from WWTFs primarily occurred in the form of nitrate. In 2006, when total annual rainfall was about 65 percent of the total rainfall that occurred in 2005 or 2007 (resulting in less nonpoint-source nutrient load), total nitrogen originating from WWTFs accounted for a larger percentage (about threefourths) of the total load in Johnson County reaches of both Indian Creek and the Blue River. Wilkison and others (2006) determined that during 2002-04, about 60 percent of the total nitrogen and total phosphorus loads in the lower Blue River in Missouri originated from Indian Creek.

- From March 2004 through December 2007, dissolved oxygen (important to sustain aquatic life) was less than the minimum state criterion of 5 milligrams per liter $(\mathrm{mg} / \mathrm{L})$ (Kansas Department of Health and Environment, 2005) less than 5 percent of the time at the five continuous monitoring sites except Blue River (8 percent) and Indian Creek (15 percent) (fig. 4). Low dissolved oxygen concentrations primarily occurred during the summer.

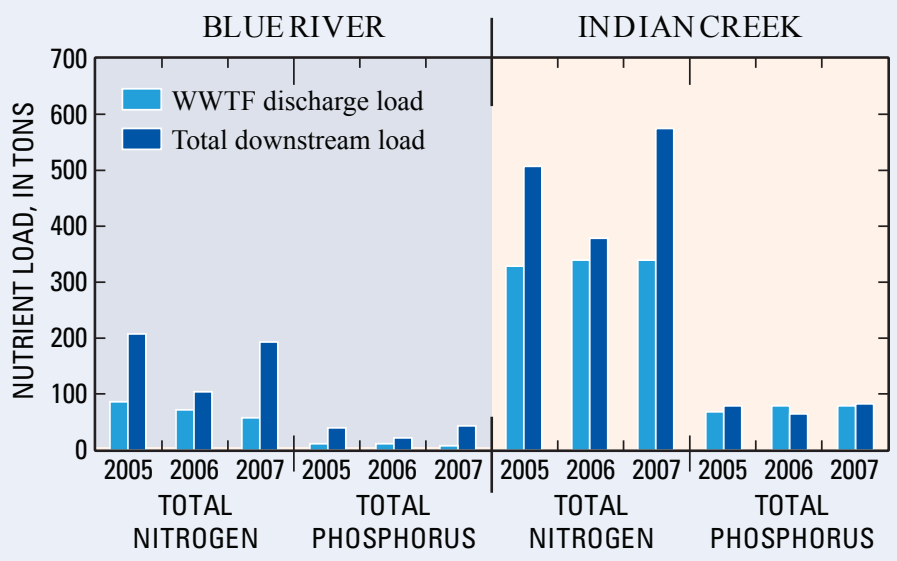

Figure 3. Annual estimated total nitrogen and total phosphorus loads and loads originating from wastewater treatment facility (WWTF) discharges in the Blue River and Indian Creek, Johnson County, Kansas, 2005-07. WWTF discharges were a primary contributor to downstream nutrient loads.

\section{Indicator Bacteria}

- Escherichia coli (E. coli) bacteria density at the Indian Creek site, located in the most urban basin, was nearly always largest with a median density more than double that of any other site. E. coli is used as an indicator of pathogens in streams that may cause illness in humans who come into contact with the water.

- During base flow, the largest bacteria densities occurred upstream from WWTFs indicating that wastewater discharges generally do not contribute substantially to bacteria densities in streams.

- During 2005-07, less than 3 percent of the total annual fecal coliform bacteria load in Indian Creek and the Blue River

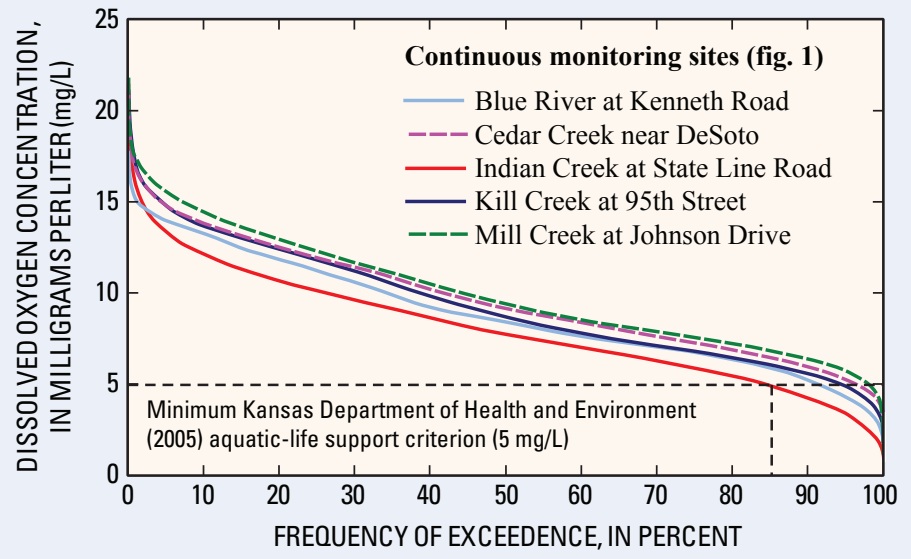

Figure 4. Measured dissolved oxygen (DO) and frequency of exceedence (percentage of time a given value is equalled or exceeded) at five continuous monitoring sites in Johnson County, Kansas, March 2004-December 2007. D0 was less than the state criterion about 15 percent of the time at the Indian Creek site.

originated from WWTFs. Wilkison and others (2006) also reported that bacteria in streams originated primarily from nonpoint sources during storm runoff.

- Water-quality conditions in streams often change rapidly during storm runoff. For example, E. coli bacteria density in Kill Creek during May 2007 increased from about 180 colonies per 100 milliliters of water $(\mathrm{col} / 100 \mathrm{~mL})$ to about 100,000 $\mathrm{col} / 100 \mathrm{~mL}$ during a 12 -hour period (fig. 5).

\section{Organic Compounds}

- Atrazine was detected in nearly all water samples, including base-flow samples, and had the largest concentrations of all pesticides sampled. Atrazine concentrations, however, did not exceed the State chronic aquatic-life criterion of 3.0 micrograms per liter $(\mu \mathrm{g} / \mathrm{L})$ as an annual average (Kansas Department of Health and Environment, 2005).

- During base flow, water samples from urban stream sites had the largest number of pesticide compounds detected, and water samples from rural sites had the largest total concentration of pesticides.

- The largest total concentrations of organic wastewater compounds occurred in base-flow samples from sites at or immediately downstream from WWTFs. The most common compounds were AHTN (acetyl-hexamethyl-tetrahydronapthalene, a musk fragrance), caffeine, DEET (mosquito repellant), a detergent surfactant (nonylphenol-diethoxylate), and a flame retardant and plasticizer (tris(2-butoxyethyl) phosphate), which together comprised more than one-half of the total organic wastewater compound concentrations in 80 percent of the base-flow samples.

- In streambed sediment samples, the largest organic compound concentrations included chlordane (an insecticide banned in 1988), dichloro-diphenyl-trichloroethane (DDT, a pesticide banned in 1972), and polyaromatic hydrocarbons (PAHs, likely carcinogens that originate from combustion of fossil fuels and are used as an ingredient in asphalt), and were present in urban basins but were not closely linked to WWTF discharges. 


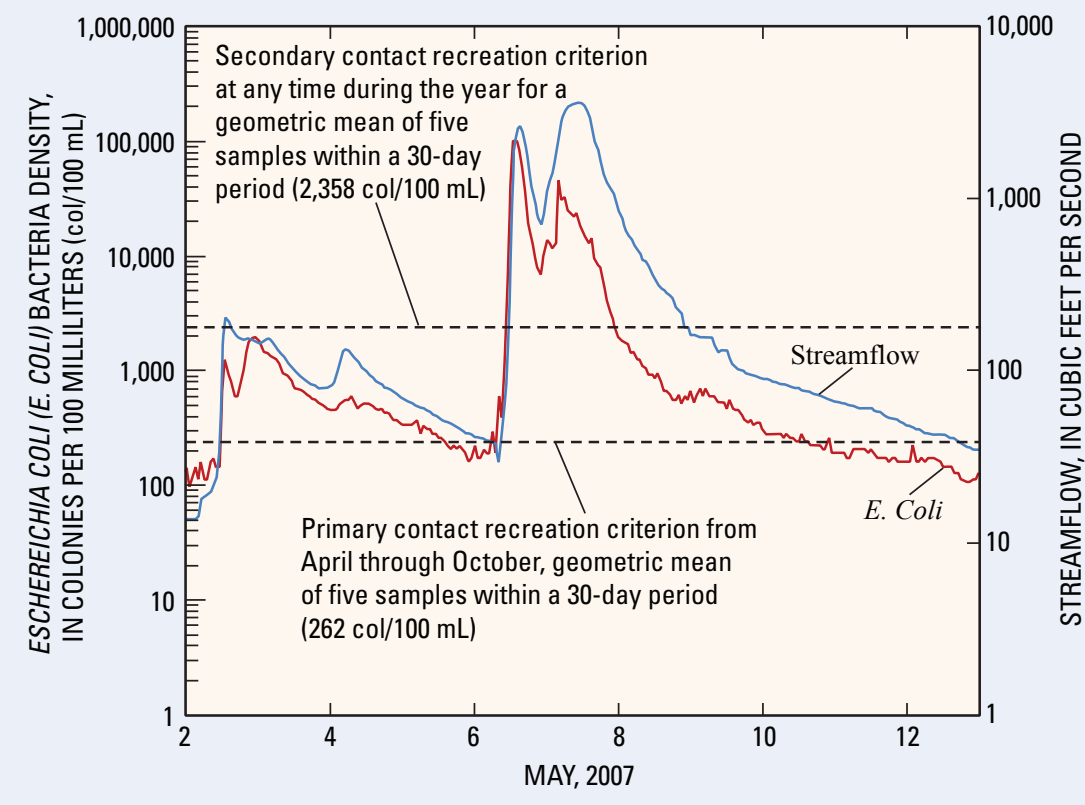

Figure 5. Streamflow and estimated E.coli bacteria density at the Kill Creek continuous monitoring site in May 2007. Bacteria density increased from about $180 \mathrm{col} / 100 \mathrm{~mL}$ to about $100,000 \mathrm{col} / 100 \mathrm{~mL}$ during a 12 -hour period.

\section{Additional Factors Affecting Water Ouality}

- Water contaminants including sediment, total nitrogen and phosphorus, bacteria, and pesticides (particularly during spring) at urban and rural sites originated primarily from nonpoint sources during storm runoff. As a consequence, climate (precipitation and resulting runoff) had a substantial effect on water quality, and larger amounts of rainfall resulted in larger amounts of contaminants. In addition, the probability that water-quality criteria are exceeded is substantially larger during storm runoff.

- Wastewater discharges were the primary source of streamflow at sites downstream from WWTFs during base-flow conditions. This is true not just immediately downstream, but many miles downstream, from the WWTF.

- About 10 percent of the time chloride concentrations in Indian and Mill Creeks were elevated as a result of runoff from road salt application; however, the acute aquatic life criterion of $860 \mathrm{mg} / \mathrm{L}$ (Kansas Department of Health and Environment, 2005) was exceeded less than 1 percent of the time.

\section{Conclusion}

Water quality of streams in Johnson County, Kansas, varied according to climate (precipitation and resulting runoff conditions), degree of urbanization, and contribution from and proximity to wastewater discharges. Results from the Johnson County water-quality studies generally were consistent with results on Blue River water quality reported by Wilkison and others (2006). Information from these studies is being used by municipal and County officials to address water-quality concerns, particularly those related to expected increases in population and urban land use leading to additional demands on streams. For example, wastewater treatment facilities on Indian
Creek and the Blue River are undergoing major upgrades to increase capacity and reduce nutrients in discharges to streams. In addition, the information is being used for public education about stormwater runoff and water quality. It also is being used to enhance and monitor programs to protect streams, such as construction runoff controls and stream setback programs. Ongoing monitoring of water quality and stream health will provide information about trends with time and effectiveness of management plans.

\section{References}

Kansas Department of Health and Environment, 2005, Kansas Administrative Regulations (KAR), Title 28, Article 16, Surface water quality standards 2005: Topeka, Kansas, Secretary of State, various pagination.

Kansas Department of Health and Environment, 2006, Kansas section (303(d) list of impaired surface waters: Information available on Web, accessed April 2007 at http://www.kdheks.gov/ tmdl/methodology.htm

Lee, C.J., Mau, D.P., and Rasmussen, T.J., 2005, Effects of point and nonpoint sources on water quality and relation to land use in Johnson County, northeastern Kansas, October 2002 through June 2004: U.S. Geological Survey Scientific Investigations Report 2005-5144, 104 p.

Paul, M.J., and Meyer, J.L., 2001, Streams in the urban landscape: Annual Review of Ecological Systems, v. 32, p. 333-365.

Poulton, B.C., Rasmussen, T.J., and Lee, C.J., 2007, Assessment of biological conditions at selected stream sites in Johnson County, Kansas, and Cass and Jackson Counties, Missouri, 2003 and 2004: U.S. Geological Survey Scientific Investigations Report 2007-5108, 68 p.

Rasmussen, T.J., Lee, C.J., and Ziegler, A.C., 2008, Estimation of constituent concentrations, loads, and yields in streams of Johnson County, northeast Kansas, using continuous waterquality monitoring and regression models, October 2002 through December 2006: U.S. Geological Survey Scientific Investigations Report 2008-5014, 103 p.

Wilkison, D.H., Armstrong, D.J., Norman, R.D., Poulton, B.C., Furlong, E.T., and Zaugg, S.D., 2006, Water quality in the Blue River Basin, Kansas City metropolitan area, July 1989 to October 2004: U.S. Geological Survey Scientific Investigations Report 06-5147, 170 p.

Publishing support provided by:

Rolla Publishing Service Center

For more information concerning this publication, contact:

Director, USGS Kansas Water Science Center

4821 Quail Crest Place

Lawrence, KS 66049

(785) 842-9909

Or visit the Kansas Water Science Center Web site at: http://ks.water.usgs.gov 